\title{
IDEAS AND METHODS OF MULTI-CENTRE STRUCTURE FORMATION OF COMPOSITE MATERIALS
}

\author{
${ }^{1}$ Vyrovoy V.M., Doctor of Engineering, Professor, \\ vyrovoy@ukr.net, ORCID: 0000-0001-8818-4112 \\ ${ }^{1}$ Korobko O.O., Doctor of Engineering, Associate Professor, \\ okskorobko71@gmail.com, ORCID: 0000-0001-7058-5268 \\ ${ }^{1}$ Kazmirchuk N.V., Ph.D., Senior Lecturer, \\ nkazmirchuk8@gmail.com, ORCID: 0000-0003-0930-2059 \\ ${ }^{1}$ Urazmanova N.F., Graduate Student, \\ nadegdaurazmanova@gmail.com, ORCID: 0000-0002-3415-4150 \\ ${ }^{1}$ Odessa State Academy of Civil Engineering and Architecture \\ 4, Didrikhson str., Odessa, 65029, Ukraine
}

\begin{abstract}
The work is devoted to the analysis of the basic mechanisms of multi-centre structure formation of building composites. The perceptions of structure evolution must include discrete sequences of irreversible «step-events». Each subsequent stage of structural development begins «from what has been achieved» and is realized with the participation and by means of inner surfaces of partition. The implementation of various mechanisms of the spontaneous emergence of local centres of structure formation leads to the organization of a multidimensional structure of the product. The multi-centre structure formation of material provides a reserve of a diversity of structures of products and constructions at various levels of heterogeneities. This sets the conditions for favourable structural changes that guarantee the resistance of products under external influences.

Keywords: composites, structural levels, multi-centre structure formation, self-organization, inner surfaces of partition.
\end{abstract}

Introduction. The experience of many generations of researchers has shown that the performance of the target functions of building products and constructions depends on the organization of the capillary-porous structure of the materials from which they are made [1,2]. Qualitative and quantitative compositions of pores and capillaries determine almost the entire set of experimental properties of materials - water absorption, capillary suction, moisture and thermal deformations, strength characteristics, frost resistance, etc. At the same time, pores, capillaries and cracks do not appear as initial elements when assigning compositions of different types and purposes of building materials. These elements spontaneously occur during technological periods of production of material and constructions and lead to non-accidental formation of localized discontinuities in an initially continuous environment. Therefore, one of the important tasks of ensuring the required operational characteristics should be the analysis of the mechanisms of spontaneous formation of inner surfaces of partition in the form of pores, capillaries and cracks in a continuous environment. This will allow determining the control factors of structure and properties of poly-structured materials.

Analysis of recent research and publications. The influence of prescription and technological factors on formation of capillary-porous structure and its subsequent influence on properties of materials are sufficiently reasoned in the special literature [3-5]. Chemical, physicochemical, physical and mechanical processes and phenomena that lead to the formation of local discrete elements in a continuous environment are researched. In our opinion, multi-centre structure formation as one of the likely mechanisms should be added to this authoritative list. The emergence of new elements in the form of surfaces of partition (pores, capillaries, cracks) for the system is not accidental as a result of the implementation of this mechanism. Multi-centre structure formation is the most initial process of organizing material structures, regardless of their nature and purpose, acting as a necessary prerequisite for the development of processes and phenomena during

Bulletin of Odessa State Academy of Civil Engineering and Architecture, 2020, no. 79, page 63-69 
hydration, polymerization, drying, melt hardening, etc. Thus, it is necessary to consider all the stages of evolutionary transitions to explain how, when, and why localized structures and inner surfaces of partition emerge in the original continuous mixtures. This will make it possible to determine the factors controlling the joint set of focal centres in poly-structured materials, which are structurally related to each other by the conditions of their emergence and development ways.

Aim and tasks. In connection with the foregoing, the aim of research was determined - to analyze the basic mechanisms of multi-centre structure formation of poly-structural composite materials and products. A control of the basic mechanisms of spontaneous emergence of discontinuities in a continuous environment should be considered the main task to achieve set aim. This will allow directional changing of the discrete periods of evolutionary structure formation to obtain complexly organized materials with given properties.

Objects and methods of research. Building poly-structural composites (products, constructions, materials) were adopted as objects of study and analysis [6]. Poly-structure assumes that at each level of heterogeneities, its own structure organization mechanism is implemented, which is characteristic of this level, with mandatory consideration of effects of interaction and interaction of different levels between each other. The method of multi-centre structure formation of building composites is the basic method of analysis. Multi-centre structure formation can be imagined as the process of spontaneous emergence of the structure-forming foci (centres) in the material. The localized structures with individual for each such structure qualitative and quantitative compositions are formed around these centres. The organization of local structures inevitably leads to the emergence and development of new structural elements for the system - surfaces of partition that can degenerate into pores, capillaries, and crack faces. In the general case, the surfaces of partition can be represented as micro-volumes of the modified material at the surfaces of partition of components (phases, structures). The surface of the components (phases, structures) itself also refers to the surfaces of partition. Phenomena and processes, that realized in the volume of components (structures, phases), occur on the interface. The interaction between components (phases, structures) takes place through the surfaces of partition. Inner and inter-cluster surfaces of partition are distinguished [7]. The inner surfaces of partition can be imagined as discontinuities in a conditionally continuous material. Inter-cluster surfaces of partition can be imagined as surfaces formed as a result of the organization of structural aggregates. Surfaces of partition are characterized by surface area and its relief, local and collective surface phenomena.

Research results. The emergence of inner surfaces of partition completes the initial stage of the evolutionary process of structure formation in continuous material and creates new conditions for the organization of fragmentary-mosaic structures at each level of heterogeneities. The uniqueness of inner surfaces of partition is that their very appearance changes the system irreversibly - significant discontinuities appear in a continuous environment. This gives reason to consider them as a peculiar interface - as the source of a communicative mediator, on the one hand, and, on the other hand, as a source of disengagement and the emergence and development of conflict between individual elements of the structure. The very fact of the formation of inner surfaces of partition requires the involvement of different fields of knowledge for analysis, leads to the generation of new meanings when describing the fragmentary structure of materials, and actualizes the transition of the system to a new state. Therefore, the perceptions of structure evolution must include discrete sequences of irreversible «step-events».

The period of self-organizing of structure-formation centres is completed when discontinuities appear. This leads to an «instant» change of the structure and «unpacking» (according to V.V. Nalimov) of new meanings (Fig. 1.). The next stage of structural development begins «from what has been achieved» and is realized with the participation and through the inner surfaces of partition. At the same time, a single mechanism of multi-centre structure formation does not exist.

Each level includes a set of structural elements characteristic only for it: clusters of binder particles and new-phase products at the micro-level; ordered cells, arbitrarily formed by the groups of aggregate in the matrix material, at the macro-level; the product (construction) itself at the product (construction) level. Respectively, this allows taking as control factors the change of: the ratio of sizes, quantities and nature of the initial binder particles (fillers); the ratio of adhesive-

Bulletin of Odessa State Academy of Civil Engineering and Architecture, 2020, no. 79, page 63-69 
cohesive bonding forces at the surfaces of partition between the matrix and the aggregates; the geometric characteristics of the product.

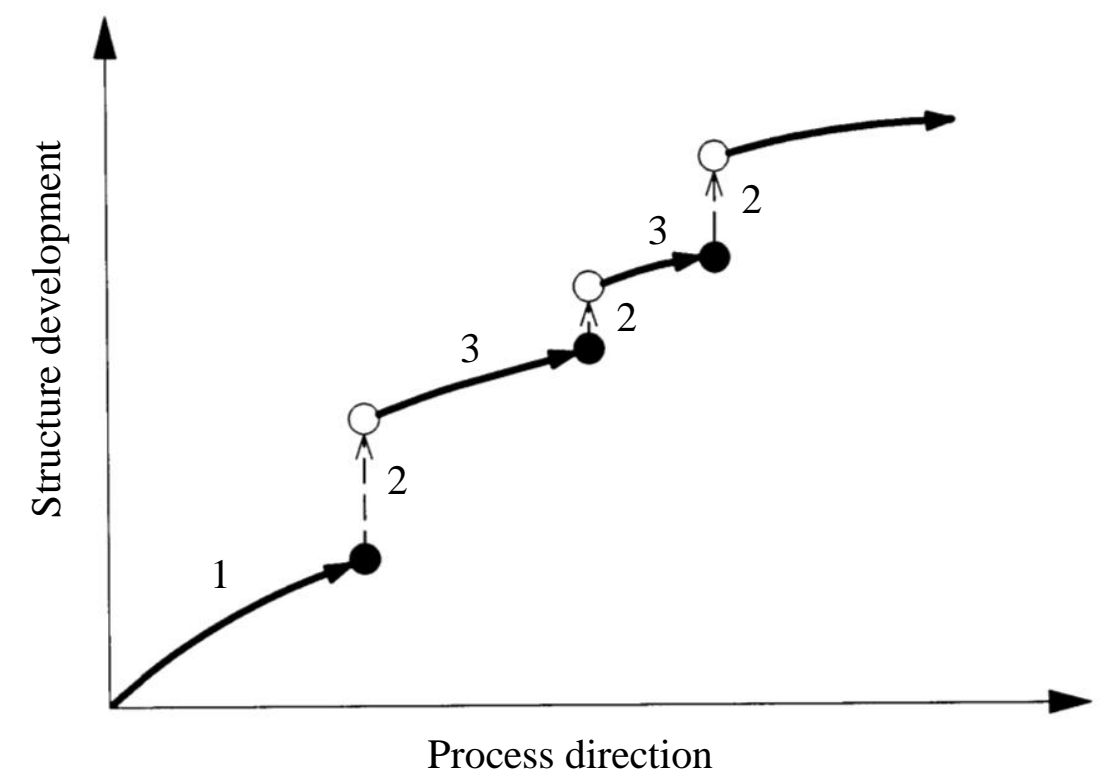

Fig. 1. Schematic diagram of multi-centre structure formation of complexly organized composites: 1 - formation of non-accidental spontaneous emergence of centres of organization of local structures; 2 - formation of structure elements that are new to the system; 3 -periods of development of the structure on the principle of «from achieved»

Structural organization at the level of the binder occurs as a result of the interaction of the initial grains of cement and particles (ions) of the products of the new phase. This leads to the formation of different-sized discrete structural blocks-clusters. The conditions for the creation of such clusters are determined by the kinetics of the development of local own deformations that arise during the interaction of the hardening matrix material with the aggregates. In turn, local deformations form and are formed against the background of the development of integral deformations. The nature of the distribution of integral deformations depends on the geometry of the products and constructions. At the same time, various mechanisms of multi-centre structure formation are realized. This leads to the organization of a multi-dimensional structure of the product. There is a unique combination of certain repeatability of discrete structures of each level with absolute non-repeatability of forms, size, and orientation, qualitative and quantitative compositions of different-sized fragments. It can be concluded that one of the basic holistic principles is inevitable - everything in the structure of the product is interrelated with as a result of feedbacks at each level and between the levels themselves.

Spontaneous occurrence of non-conforming by qualitative and quantitative composition of clusters leads to increased of non-conformance by type of clusters from products of new growths. This is particularly the case with the amorphous (vitreous) phase, which can be up to $80 \%$ of the total hydration products. The integration of particles into blocks involves inter-particle contact. This stimulates the processes of volume surface diffusion mass transfer and diffusion mass transfer through the dispersion phase - the manifestation of «cold sintering» effects [8]. Mass transfer through the volume of particles and their surface involves the migration of ions that are not involved in the chemical processes of hydration. This will diversify the qualitative composition of the microstructure, since the material of the contact isthmus consists mainly of the material of the parent particles. Such qualitative composition is difficult to identify by existing methods of qualitative and quantitative analysis.

The formation of different scale fragments completes the initial path of structural organization and anticipates further processes of structural organization, taking into account the emergence of new different-level surfaces of partition in the system. The evolutionary path involves a further analysis of the behaviour of the system «from what has been achieved» (Fig. 2). 


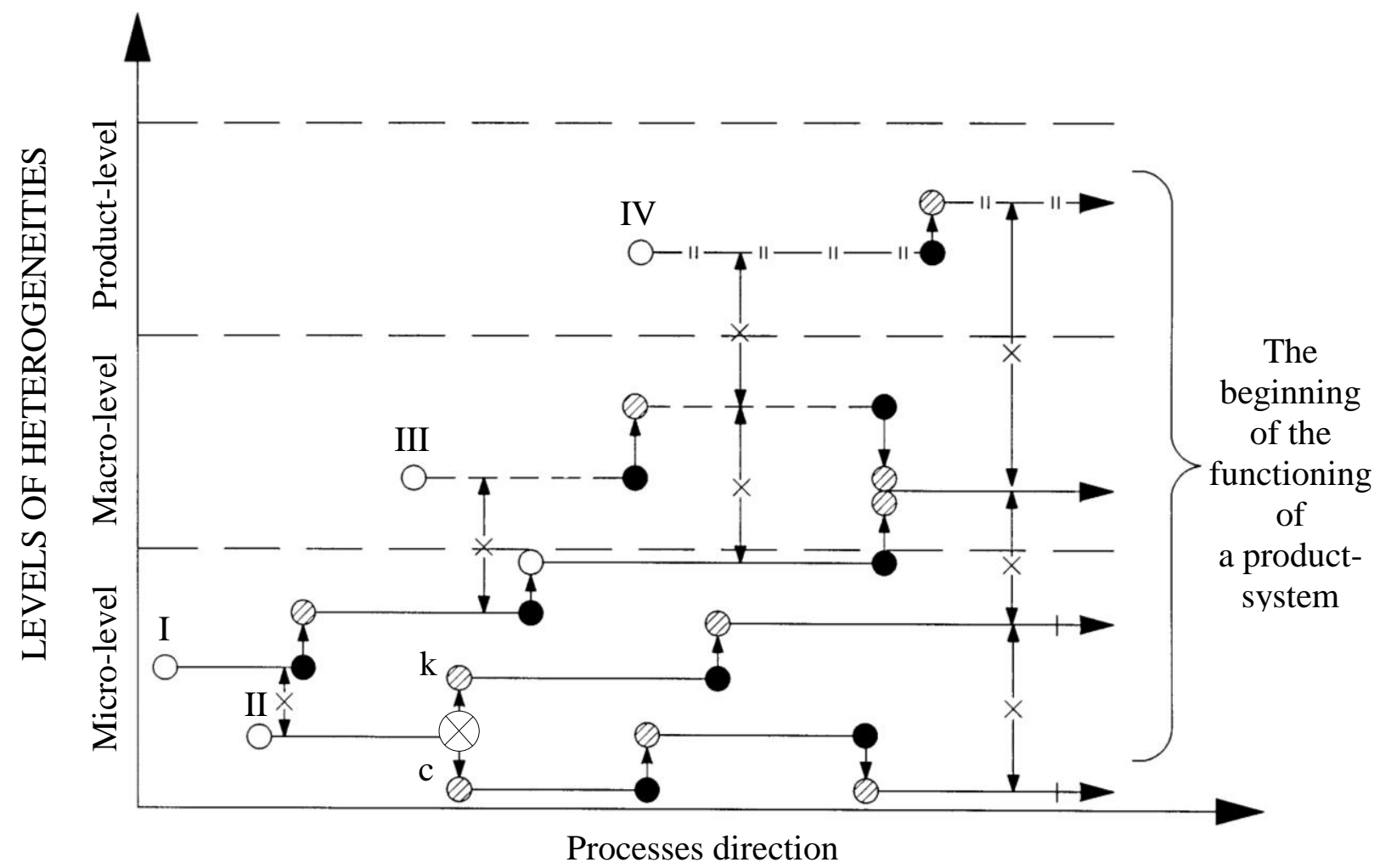

Fig. 2. Scheme of co-evolutionary shifts of structure of poly-structural materials based on inorganic binders:

I - the beginning of the process at the level of the initial binder; II - the beginning of the process at the level of products of new growths; III - the beginning of the process at the concrete level; IV - the beginning of the process at the product level; $\mathrm{k}$ - the beginning of the process of crystal nucleation and growth; $\mathrm{c}$ - the beginning of the process of organization of the vitreous phase structure;

$\$$ - Mutual influence of processes on structure transformations of different heterogeneities;

- The period of emergence of fundamentally new elements of the structure;

- Completion of influence of new elements on the structure organization of different levels;

- The period of the qualitative and quantitative shift of individual level structures

The implementation of multi-centre structure formation at different levels of heterogeneities produces the manifestation of an emergent interface not only within each level, but also between different levels. Discrete «steps-events» at each level involve the development of new scenarios for the development of structures «from what has been achieved». Inner surfaces of partition are transformed into other elements with the next stage of discontinuities occurrence.

As characteristic mechanisms of multi-centre structure formation for poly-structural composites can be distinguished: mechanisms of unbalanced inter-particle interactions for the initial binders and thermo-fluctuation effects of critical nucleation concentration for the products of new growths; mechanisms of interaction of matrix material with aggregates; mechanisms of the influence of geometric characteristics of products on the formation of residual deformations, which determines the processes of structure organization of all levels.

An increase in the diversity of cluster structures, unique in shape, size, and composition, at the levels of a microstructure and products of new growths, is reflected in the kinetics of volume deformations and the setting time of hardening material. With certain changes in filler compositions and parameters of external influences, the structures of cement and polymer-containing composites were obtained, providing increased values of compressive strength up to $39 \%$, crack resistance up to 2 times, elastic modulus up to 2.5 times.

Bulletin of Odessa State Academy of Civil Engineering and Architecture, 2020, no. 79, page 63-69 
Structural cells formed by groups of aggregates in matrix material are unique in size, shape and conditions of interfacial interactions. Therefore, each structural cell is an individual unique centre of structural formation. This is confirmed by the various in values and kinetics of volume deformations and the setting times in different cells. Depending on the quantity and relative orientation of placeholders in structural cell models, the values of initial volume deformations of the cement matrix were changed by $7-44 \%$, the setting time by $20-150 \mathrm{~min}$. The use of aggregates with different surface conditions allows diversifying the conditions of macrostructure formation even in concrete of the same composition. Damage of cement matrix by initial cracks and inner surfaces of partition in samples with different sets of cells differed up to $45 \%$, water absorption value up to $45 \%$, compression strength up to 2 times. As a result, structures were obtained that provide an improvement in the properties and resistance of the product material at low-cycle fatigue compared to products on concrete with traditional compositions. At fracture of samples, the length of the main crack was $18 \%$ less in concrete with selective adhesion of the matrix to aggregates, due to a more developed network of initial cracks and inner surfaces of partition, i.e. those concretes that included a more complex set of structural cells.

Changing the geometry of the products exacerbates the uniqueness of the distribution of local and integral initial deformations, which act as centres of concrete structure formation at the product level. Regulation of the conditions of multi-centre organization of the structure due to the design of the shape of small-piece products and concrete beams allowed to reduce the gradients of residual deformations and, thereby, increase their mechanical properties. Experimental results showed that a change in the conditions for the formation of fields of technological deformations due to a change of the shape of one of beam faces resulted to a change in the density of the material up to $190 \mathrm{~kg} / \mathrm{m}^{3}$, compressive strength up to $30 \%$, and a decrease in water absorption up to $20 \%$ over the product cross-section.

Multi-centre structure formation is typical of virtually all complexly organized materials and products obtained by drying, cooling, polymerization and poly-condensation, hydration, etc. Multilevel multi-centre structure formation creates the conditions for formation of multilevel individual fragmentary-mosaic structures. The initial composition of the material and technological modes of production of products have the most significant effect on the formation of different-level relatively independent parts-fragments. The appearance of fragments inevitably leads to the emergence and perspective of the development of inner surfaces of partition, which predetermine subsequent evolutionary transformations of structures.

Conclusions. The analysis made it possible to establish that multi-centre structure formation is an objectively existing phenomenon of structural formation of composite construction materials. In turn, an analysis of the mechanisms of multi-centre structure formation showed that fundamentally different mechanisms lead to the spontaneous emergence of new elements for each level of structural heterogeneities - inner surfaces of partition. Further processes of evolutionary transformations of the structure of the material and products are determined by the conditions for the transformation of the resulting surfaces of partition into pores, capillaries and cracks. This is the subject of further research. The multi-centre structure formation of building composites provides a reserve of the diversity of their structures at various levels of heterogeneities. This sets the conditions for favourable structural changes, which guarantees the resistance of products under external influences.

\section{References}

[1] P.V. Krivenko, E.K. Pushkarova, V.I. Gots, G.Yu. Kovalchuk, Tsementyi i betonyi na osnove toplivnyih zol i shlakov. Kiev : Eksperess-Poligraf, 2012.

[2] L.I. Dvorkin, V.I. Solomatov, V.N. Vyirovoy, S.M. Chudnovskiy, Tsementnyie betonyi s mineralnyimi napolnitelyami. Kiev : BudIvelnik, 1991.

[3] M.A. Sanytskyi, Kh.S. Sobol, T.Ie. Markiv, Modyfikovani kompozytsiini tsementy. Lviv : NU «Lvivska politekhnika», 2010.

[4] L.I. Dvorkin, Ye.M. Babych, V.V. Zhytkovskyi ta in., Vysokomitsni shvydkotverdnuchi

Bulletin of Odessa State Academy of Civil Engineering and Architecture, 2020, no. 79, page 63-69 
betony ta fibrobetony. Rivne : Natsionalnyi universytet vodnoho hospodarstva ta pryrodokorystuvannia, 2017.

[5] Y. Shtark, B. Viht, Tsement i izvest. Kiev, 2008.

[6] V.G. Suhanov, V.N. Vyirovoy, O.A. Korobko, Struktura materiala v strukture konstruktsii. Odessa : POLIGRAF, 2016.

[7] V.N. Vyirovoy, V.S. Dorofeev, V.G. Suhanov, Kompozitsionnyie stroitelnyie materialyi i konstruktsii. Struktura, samoorganizatsiya, svoystva. Odessa : TES, 2010.

[8] Ya. E. Geguzin, Fizika spekaniya. Moskva : Nauka, 1984.

\title{
ІДЕЇ ТА МЕТОДИ БАГАТООСЕРЕДКОВОГО СТРУКТУРОУТВОРЕННЯ КОМПОЗИЦІЙНИХ МАТЕРІАЛІВ
}

\author{
${ }^{1}$ Вировой В.М., д.т.н., професор, \\ vyrovoy@ukr.net, ORCID: 0000-0001-8818-4112 \\ ${ }^{1}$ Коробко О.О., д.Т.н., доцент, \\ okskorobko71@gmail.com, ORCID: 0000-0001-7058-5268 \\ ${ }^{1}$ Казмірчук Н.В., к.т.н., ст. викладач, \\ nkazmirchuk8@gmail.com, ORCID: 0000-0003-0930-2059 \\ ${ }^{1}$ Уразманова Н.Ф., аспірант, \\ nadegdaurazmanova@gmail.com, ORCID: 0000-0002-3415-4150 \\ ${ }^{1}$ Одеська державна академія будівництва та архітектури \\ вул. Дідріхсона, 4, м. Одеса, 65029, Україна
}

\begin{abstract}
Анотація. Багатоосередкове структуроутворення $є$ об'єктивно існуючим феноменом утворення структур будівельних композитів, незалежно від їх природи та призначення. Під багатоосередковим структуроутворенням слід розуміти процес спонтанного виникнення в матеріалі структуроутворюючих осередків (центрів), навколо яких утворюються локалізовані структури 3 індивідуальним для кожної структури якісним та кількісним складами. Важливою задачею забезпечення потрібних властивостей виробів і конструкцій слід вважати аналіз механізмів самовільного утворення в безперервному середовищі внутрішніх поверхонь розділу у вигляді пор, капілярів та тріщин. Це дозволить визначити фактори керування солідарною множиною структурно зв'язаних осередкових центрів у поліструктурних матеріалах. Тому метою досліджень було проаналізувати основні механізми багатоосередкового структуроутворення композиційних матеріалів. Уявлення про еволюцію структури має включати в себе дискретні послідовності незворотних «кроків-подій». Кожний наступний етап структурного розвитку починається «від досягнутого» та реалізується за участю та через внутрішні поверхні розділу. Структурне оформлення на рівні в'яжучого відбувається в результаті взаємодії вихідних часток цементу та продуктів нової фази, що веде до утворення різномасштабних дискретних структурних агрегатів - кластерів. Умови організації визначаються кінетикою розвитку локальних власних деформацій, які виникають при взаємодії матричного матеріалу, що твердіє, з поверхнею заповнювачів. У свою чергу локальні деформації формують та формуються на фоні розвитку інтегральних деформацій, характер розподілу яких залежить від геометрії виробів та конструкцій. При цьому реалізуються різні механізми багатоосередкового структуроутворення, що веде до організації багатомірної структури виробу. Відбувається своєрідне узагальнення непоєднуваних за якісними ознаками елементів в об'ємі матеріалу одного виробу. Подальші процеси еволюційних перетворень структури матеріалу та виробів визначаються умовами трансформації поверхонь розділу, що виникли, в пори, капіляри та тріщини. Багатоосередкове структуроутворення будівельних композитів забезпечує резерв різноманіття їх структур на різних рівнях неоднорідностей. Цим задаються умови для сприятливих структурних змін, що гарантує стійкість виробів при зовнішніх впливах.

Ключові слова: композити, поліструктурність, багатоосередкове структуроутворення, самоорганізація, внутрішні поверхні розділу.
\end{abstract}




\title{
ИДЕИ И МЕТОДЫ МНОГООЧАГОВОГО СТРУКТУРООБРАЗОВАНИЯ КОМПОЗИЦИОННЫХ МАТЕРИАЛОВ
}

\author{
${ }^{1}$ Выровой В.Н., Д.т.н., профессор, \\ vyrovoy@ukr.net, ORCID: 0000-0001-8818-4112 \\ ${ }^{1}$ Коробко О.А., д.Т.н., доцент, \\ okskorobko71@gmail.com, ORCID: 0000-0001-7058-5268 \\ ${ }^{1}$ Казмирчук Н.В., к.т.Н., ст. преподаватель, \\ nkazmirchuk8@gmail.com, ORCID: 0000-0003-0930-2059 \\ ${ }^{1}$ Уразманова Н.Ф., аспирант, \\ nadegdaurazmanova@gmail.com, ORCID: 0000-0002-3415-4150 \\ ${ }_{1}^{1}$ Одесская государственная академия строительства и архитектуры \\ ул. Дидрихсона, 4, г. Одесса, 65029, Украина
}

\begin{abstract}
Аннотация. Многоочаговое структурообразование является объективно существующим феноменом образования структур строительных композитов, независимо от их природы и назначения. Под многоочаговым структурообразованием следует понимать процесс самопроизвольного возникновения в материале структурообразующих очагов (центров), вокруг которых образуются локализованные структуры с индивидуальным для каждой структуры качественным и количественным составами. Важной задачей обеспечения требуемых свойств изделий и конструкций следует считать анализ механизмов самопроизвольного образования в непрерывной среде внутренних поверхностей в виде пор, капилляров и трещин. Это позволит определить факторы управления солидарным множеством структурно связанных очаговых центров в полиструктурных материалах. Поэтому целью исследований было проанализировать основные механизмы многоочагового структурообразования композиционных материалов. Представление об эволюции структуры должно включать в себя дискретные последовательности необратимых «шагов-событий». Каждый следующий этап структурного развития начинается «от достигнутого» и реализуется при участии и посредством внутренних поверхностей раздела. Структурное оформление на уровне вяжущего происходит в результате взаимодействия исходных зерен цемента и продуктов новой фазы, что ведет к образованию разномасштабных дискретных структурных агрегатов - кластеров. Условия создания таких кластеров определяются кинетикой развития локальных собственных деформаций, которые возникают при взаимодействии твердеющего матричного материала с заполнителями. В свою очередь локальные деформации формируют и формируются на фоне развития интегральных деформаций, характер распределения которых зависит от геометрии изделий и конструкций. При этом реализуются различные механизмы многоочагового структурообразования, что ведет к организации многомерной структуры изделия. Происходит своеобразное обобщение несочетаемых по качественным признакам элементов в объеме материала одного изделия. Дальнейшие процессы эволюционных преобразований структуры материала и изделий определяются условиями трансформации возникших поверхностей раздела в поры, капилляры и трещины. Многоочаговость структурообразования строительных композитов обеспечивает резерв разнообразия их структур на различных уровнях неоднородностей. Этим задаются условия для благоприятных структурных изменений, что гарантирует стойкость изделий при внешних воздействиях.
\end{abstract}

Ключевые слова: композиты, полиструктурность, многоочаговое структурообразование, самоорганизация, внутренние поверхности раздела.

Стаття надійшла до редакції 10.03.2020

Bulletin of Odessa State Academy of Civil Engineering and Architecture, 2020, no. 79, page 63-69 